\title{
On the Study of Hybrid Riser with Integrated Tether for Extreme Offshore Conditions in the Gulf of Guinea
}

\author{
Francisca Amarachukwu Duru ${ }^{1}$, Chinwuba Victor Ossia ${ }^{1,}$, John Chukwudi Uzoewulu² \\ ${ }^{1}$ Offshore Technology Institute, ETF Gas Engineering Building, University of Port Harcourt, Port Harcourt, Nigeria \\ ${ }^{2}$ Health, Safety \& Environment Department, Port Harcourt Refining Company, Nigeria National Petroleum Corporation, Eleme, Port \\ Harcourt, Nigeria
}

Email address:

ossiacv@otiuniport.org (C. V. Ossia)

${ }^{*}$ Corresponding author

\section{To cite this article:}

Francisca AmarachukwuDuru, Chinwuba Victor Ossia, John Chukwudi Uzoewulu. On the Study of Hybrid Riser with Integrated Tether for Extreme Offshore Conditions in the Gulf of Guinea. International Journal of Mechanical Engineering and Applications.

Vol. 5, No. 1, 2017, pp. 52-59. doi: 10.11648/j.ijmea.20170501.17

Received: December 20, 2016; Accepted: December 30, 2016; Published: March 2, 2017

\begin{abstract}
This study presents the optimization of the hybrid risers in deepwater applications by the integration of a tether. It analyses the feasibility, impact and essence of attaching Polyester tether to the buoy of a conventional hybrid system using the Gulf of Guinea (GoG) wave conditions, and adopting a water depth of $1800 \mathrm{~m}$. The sensitivity of the convectional hybrid riser (CHR) and Tethered-Hybrid Riser system (THRS) were also analyzed and compared to observe its response with respect to effective tension and maximum von Mises stress. The findings reveals that the effective tension and stress experienced a $2.5 \%$ and $6.4 \%$ reduction for the fixed standing hybrid riser (FSHR) and flexible jumper, respectively; for the THRS when compared to the CHR configuration (with 10-years wave return period). The results also show that there should be appropriate vessel control in order to maintain the best response when in service over 10-year and 100-years extreme conditions. Hence, the Tethered Hybrid Riser System (THRS) yields a significant improvement when compared to the CHR.
\end{abstract}

Keywords: Tethered Hybrid Riser, Conventional Hybrid Riser, Fixed Standing Hybrid Riser

\section{Introduction}

\subsection{Background}

Internationally, in the last 10 years, the exploration, production and development in the deep water $(>500 \mathrm{~m}$ depth) has expanded, this has accounted for more than half of the global oil and gas reserves. The statistical evaluation from 2005 to 2009 by Information History Service (IHS) on discovery recorded that ultra-deepwater $(>1500 \mathrm{~m}$ depth) accounted for $41 \%$ of the total newly discovered reserves. However, despite these huge advances, setbacks such as technological challenges, harsh environmental conditions, production cost, etc; limits the overall offshore operations. Hence, there is still room for improvement.

One of the major challenges encountered in offshore oil and gas operations is the link between the floater and subsea structures on the seabed (Marine riser and mooring lines). Riser systems are used to transport fluids (or serve as service line as in the case of umbilical (UFL)) between a well head or subsea structure(s) on the seabed and a fixed platform (or a floating vessel) on the free surface. However, challenging factors such as the hydrostatic pressure, current, ocean waves and vessel's motion pose a difficult challenge for riser design engineers.

\subsection{Riser Systems}

According to Mungall, et al. [1], a production riser system is a fluid communication system which usually includes multiple conduits through which various produced fluids (for instance, oil, gas, water, etc.) are transported between the production facility at the water surface and the seabed. Though, used for export / off-loading lines, fluid injection lines; some riser system can also serve as service, electrical and hydraulic lines.

There are primarily two kinds of risers, they are rigid and flexible risers; the hybrid riser is the integration of these two 
kinds of riser system [2]. A typical riser system is composed of the conduit (riser body), interface with floater and wellhead, Components, and Auxiliary.

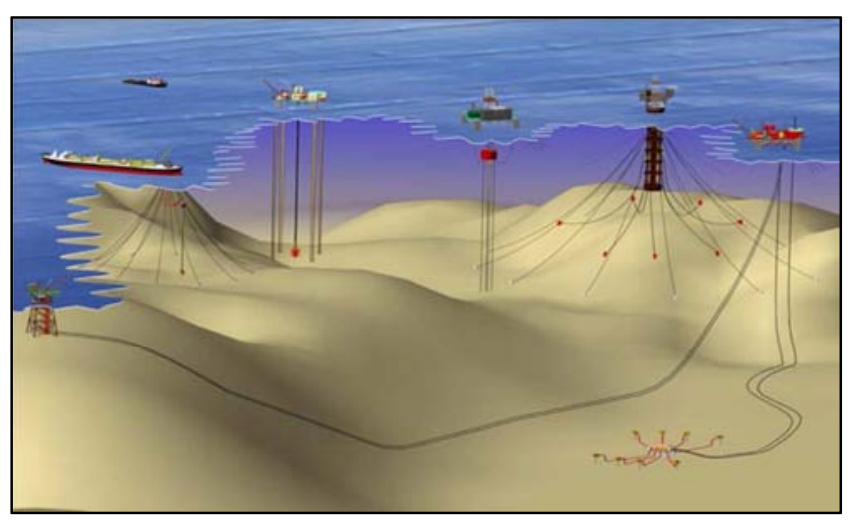

Figure 1. Different Riser Systems [3].

\subsubsection{Flexible Riser System}

The typical structural configuration of a flexible pipe consist of an inner most layers of interlocked metallic construction to prevent collapse of the internal pressure sheath or pipe, steel helically wound and interlocked layers to support the internal pressure sheath, increase resistance to internal and external loads and mechanical crushing loads, and polymer sealing layers to provide fluid integrity, protection from corrosion and abrasion [4]. Due to the structural configuration and the different material used to make the wall of the riser, the flexible riser (when compared to the equivalent steel riser) has a low relative bending to axial stiffness. Other advantages include the ability to be stored in long lengths of reels, hence reducing transportation and installation cost. The Flexible riser configurations can be grouped as free hanging catenary, wave configuration (lazy wave, steep wave, plaint wave) and S-type configuration.

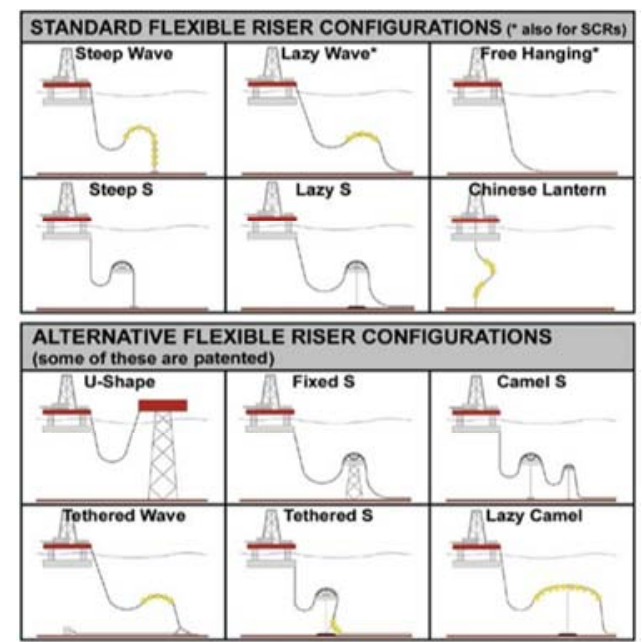

Figure 2. Various flexible riser system configurations. [5].

\subsubsection{Rigid Riser System}

This type of riser system can be classified into Steel catenary riser (SCR), Top Tension Riser (TTR). SCR is a riser system which has one end of the rigid submerged riser curved upward in a catenary form from the touchdown point to the floating production unit by a flex-joint [6]. The first SCR to be installed with a semi-submersible was applied in the Marlim field offshore Brazil [7]. Also, in 2004, oil and gas export SCRs were installed in the Bonga Oil field on an FPSO in West Africa.

TTR allows direct access to subsea wells from a floating production unit (or platform for drilling, work over or completion operations) [8]. This concept consists of the main riser tensioning system such as RAM tensioners, tensioners deck, traditional hydraulic tensioners and counterweight; Riser guides / Centralizers; Keel joint at keel; Surface well / Bop stack on a production tress and jumpers; Stress Joint and tie back connector; Vortex Induced Vibration (VIV) Suppression devices.

\subsubsection{Hybrid Riser System}

The Hybrid riser system is a combination of a jumper (steel or flexible) and a standing vertical riser. The major advantage of this concept is that it accommodates the relative motion between the floating production unit and the standing riser by joining them with flexible jumpers; it also gives a clearer and organized subsea layout which is principal in field development [9]. The hybrid riser system can come in the following configurations:

a) The Bundle Hybrid Riser System

This was first installed in Green Canyon Block 29 of the Gulf of Mexico (GoM) in 1,529ft of water depth; this type of hybrid riser can incorporate efficiently 10-12 lines in a single structure in the year 1988 [10]. According to Dale and Karunakaran [11], this concept has reduced installation cost and number of risers, however, the challenge of routing the flowline, pipe expansion, thermal/flow assurance are encountered.

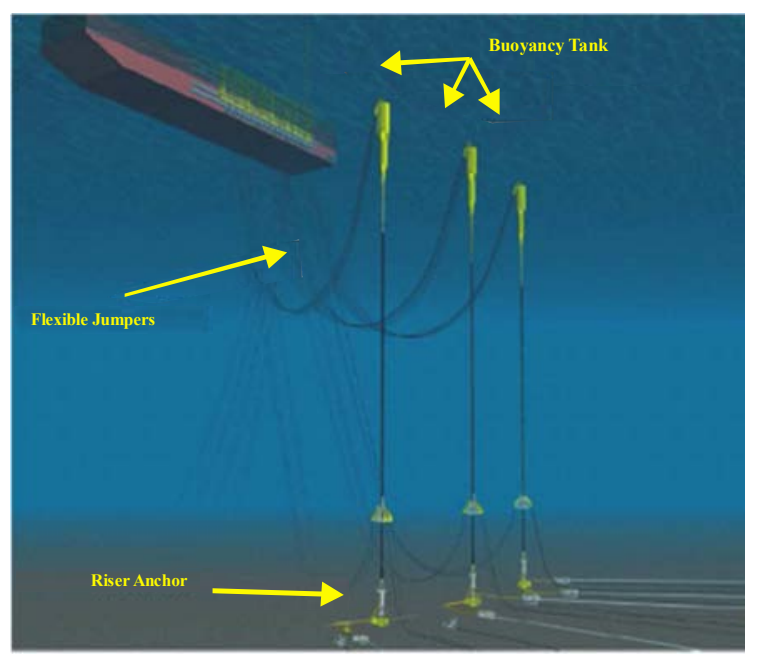

Figure 3a. Bundled Hybrid Riser Diagram [3].

b) The Single Line Offset Riser (SLOR)

The SLOR employs a vertical steel riser section that is linked to the host vessel via a flexible pipe jumper. The key advantage of this hybrid arrangement is that the vertical riser response is largely decoupled from the vessel motions and 
hence becomes less susceptible to fatigue damage. However, since the SLOR are well spaced to allow for large deflections (as a result of the current loading) the number of SLORS that can be accommodated in a particular field could be limited and not enough [11]. In 2004/2005, Exxon installed the first SLOR in Kizomba A and B in water depth ranging from 3,300 to $4,200 \mathrm{ft}$ [10].

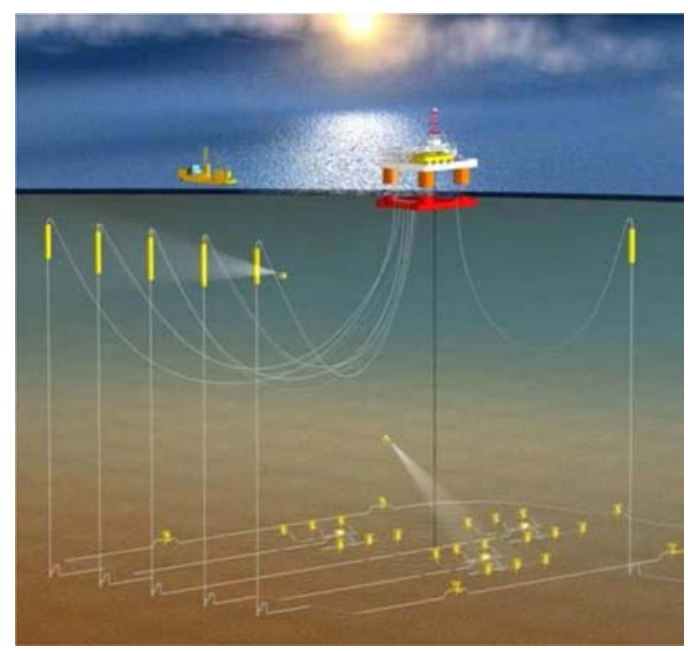

Figure 3b. SLOR Production System arrangement [12].

\section{Methodology}

In this design analysis, standard design codes for riser system was used, as this gives the criteria, requirement and guidance on the structural design and analysis of all riser systems exposed to static and dynamic loading for use in the oil and gas sector. Det Norske Veritas (DNV) [13] DNV-OSF201 Offshore Standards for dynamic risers and American Petroleum Institute [14] API RP 2RD standards for risers attached to floating systems will be used as reference code. This design codes are embedded in Orcaflex which is the FEA tool adopted here. Orcaflex FEA tool is a marine program developed for static and dynamic analysis of offshore structures (risers, mooring lines), global analysis, installation and towed systems [15].

Using the Orcaflex FEA tool, preliminary analysis with respect to maximum von Mises stress and Effective tension was carried out on a Tethered Hybrid riser as well as the conventional hybrid riser.

\subsection{Tethered Hybrid Riser Design}

The model consists of a vertical rigid steel pipe of length $800 \mathrm{~m}$ with an outer diameter of 12.75 in $(0.324 \mathrm{~m})$ anchored to the seabed and offset by $950 \mathrm{~m}$ from the vessel static position, it is tensioned by means of a cylindrical buoyancy-Can of $30 \mathrm{~m}$ by $5 \mathrm{~m}$ which is $970 \mathrm{~m}$ below sea level; this provides the required uplift force. A flexible jumper of length $1600 \mathrm{~m}$ and diameter of 12.75 in $(0.324 \mathrm{~m})$ connects the rigid riser to the vessel. A tether is integrated into the system to station keep the buoyancy device in position during extreme events.

The objective of the analysis is to obtain riser response (both for THR and HR) by applying Gulf of Guinea environmental conditions and FPSO heading; to check the performance of the Tethered Hybrid riser (THR) against the convectional hybrid riser (CHR) system.

\subsection{Environmental Data}

The water depth used in this analysis was $1800 \mathrm{~m}$, with sea water density of $1025 \mathrm{~kg} / \mathrm{m}^{3}$. The submerged buoy is located $970 \mathrm{~m}$ below the sea surface. This system configuration adopted in this study is similar to that of Andueza et al [16] in the design of an Ultra-Deep-water steel hybrid riser concept for offshore Brazil.

The wave condition was modeled by random (irregular) waves, Ochi-Hubble waves, spectrum in order to accommodate the behavior of the riser system. Significant wave height $\mathrm{H}_{\mathrm{s}}=6.21 \mathrm{~m}$ and $\mathrm{H}_{\mathrm{s}}=8.23 \mathrm{~m}$ for 10 -years and 100-years recurrence period, respectively, with a corresponding the pitch $\mathrm{T}_{\mathrm{p}}=7.65 \mathrm{~s}$ and $\mathrm{T}_{\mathrm{p}}=8.07 \mathrm{~s}$, respectively. The current profile of GoG includes a surface current speed of $1.0 \mathrm{~m} / \mathrm{s}$ and $1.22 \mathrm{~m} / \mathrm{s}$, respectively, with corresponding seabed values of $0.38 \mathrm{~m} / \mathrm{s}$ and $0.46 \mathrm{~m} / \mathrm{s}$, for 10 years and 100-years recurrence, respectively.

\subsection{Flowline Data}

\subsubsection{Riser Material}

The riser steel material should have adequate strength, fracture toughness and weld-ability. It should not yield under stress or fail due to mechanical load; the riser material adopted is X65 $(65,000 \mathrm{Psi})$ carbon steel pipe with a density of $7.85 \mathrm{te} / \mathrm{m}^{3}$ for the flexible jumper.

Table 1. Riser Size and Mechanical properties.

\begin{tabular}{lll}
\hline Parameters & Value & Unit \\
\hline Pipe Line length FSHR & 800 & $\mathrm{~m}$ \\
Outer Diameter FSHR & 0.330 & $\mathrm{~m}$ \\
Inner Diameter FSHR & 0.229 & $\mathrm{~m}$ \\
Pipe Line length Flexible jumper & 1600 & $\mathrm{~m}$ \\
Outer Diameter Flexible jumper & 0.324 & $\mathrm{~m}$ \\
Inner Diameter Flexible jumper & 0.273 & $\mathrm{~m}$ \\
Torsional Stiffness FSHR & $73.231 \mathrm{E} 3$ & $\mathrm{kNm}^{-2}$ \\
Axial Stiffness FSHR & $9.312 \mathrm{E} 6$ & $\mathrm{kN}^{-2}$ \\
Bending Stiffness FSHR & $95.9 \mathrm{E} 3$ & $\mathrm{kNm}^{-2}$ \\
Bending Stiffness Flexible jumper & $56.339 \mathrm{E} 3$ & $\mathrm{kNm}^{-2}$ \\
Axial Stiffness of Flexible jumper & $5.022 \mathrm{E} 6$ & $\mathrm{kN}^{-2}$ \\
Torsional Stiffness Flexible jumper & $43.338 \mathrm{E} 3$ & $\mathrm{kNm}^{-2}$ \\
\hline
\end{tabular}

\subsubsection{Tether Data}

The buoyancy acting on top of the standing riser is held by a pre-tensioned tether which serves as station keeping. According to American Petroleum Institute [17] the application of polyester material for the tether than steel is to lower the maximum tension and offset; the application of polyester lines brings about reduced damping than the use of steel lines, this is due to the inability of the polyester line to become catenary under wave frequency motion. Tether (Tensioned Rope) mechanical properties include: diameter $=0.043 \mathrm{~m}$, weight in air $\mathrm{W}_{\mathrm{a}}=$ $0.016 \mathrm{kN} / \mathrm{m}$; weight in water $\mathrm{W}_{\mathrm{w}}=0.0016 \mathrm{kN} / \mathrm{m}$; Axial stiffness $=295 \mathrm{kN}$; Torsional stiffness $=80 \mathrm{kNm}$. 


\subsubsection{Vessel Properties}

A turret moored Floating Production Storage and Offloading (FPSO) unit of $241.78 \mathrm{~m}$ in length was adopted in this analysis, the vessel motion characteristics (six degree of freedom, Heave, Surge, Sway, Roll, Pitch, and Yaw) and response is very important in this design as the Hybrid riser's integral parts comprising of the flexible jumper, standing riser, buoyancy can and tether are linked to the vessel.

For these analyses, the Hybrid riser system was specified with the following Load types:

- Wave return periods: 10-years $(6.21 \mathrm{~m}$ height at 7.65 seconds); 100years ( $8.23 \mathrm{~m}$ height at 8.07 seconds);

- Wave direction: $0^{\circ}, 90^{\circ}, 180^{\circ}$ and $270^{\circ}$;

- Current speed: $1.0 \mathrm{~m} / \mathrm{s}, 1.22 \mathrm{~m} / \mathrm{s}$;

- Vessel headings: $0^{\circ}, 22.5^{\circ}, 45^{\circ}, 67.5^{\circ}, 90^{\circ}, 112.5^{\circ}$, $135^{\circ}, 157.5^{\circ}, 180^{\circ}$.

\section{Results and Discussion(s)}

This section shows the effective tension and maximum von Mises stress occurring at the top end of the FSHR and flexible jumper of a CHR and a THR while varying wave direction and vessel heading; it is aimed at displaying the vessel headings to be avoided during a particular wave direction. This section further shows a comparison between a CHR and a THR with respect to the maximum von Mises stress and effective tension.

\subsection{Design Analysis of Conventional Hybrid Riser Without the Integrated Tether}

The sensitivity of the top end of the FSHR and flexible jumper of the conventional Hybrid riser with respect to effective tension and maximum von Mises stress were carried out.

\subsubsection{Sensitivity of Fixed Standing Hybrid Riser (FSHR) for 10-Years Wave Period}

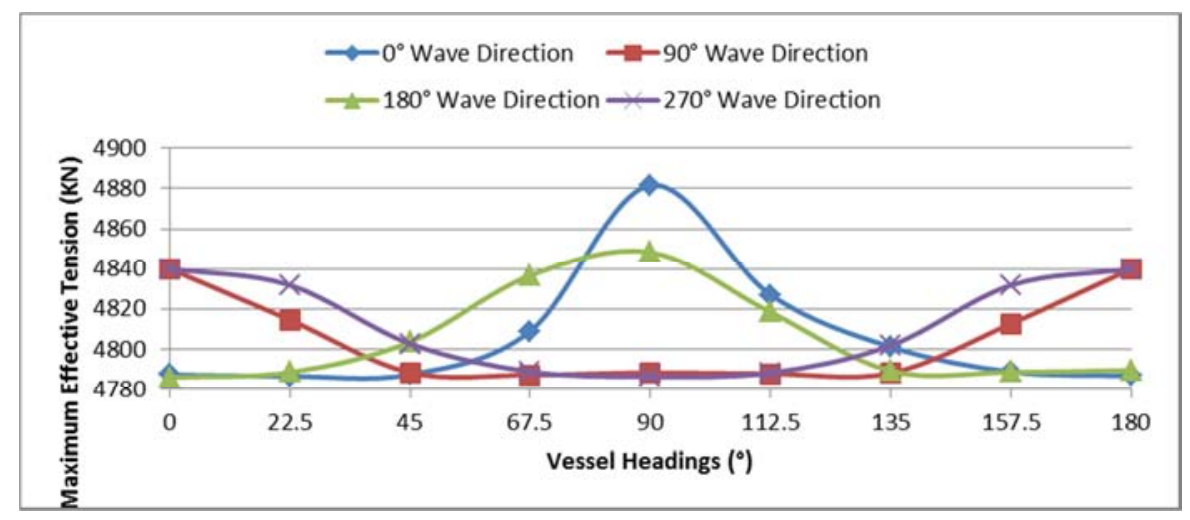

Figure 4. Effective top-end Tension of the FSHR for 10-years wave period for different wave directions.

From figure 4 above, the highest effective tension on the FSHR while varying vessel heading (V) and wave direction (W) is $4881.6 \mathrm{kN}\left(\right.$ at $0^{\circ}(\mathrm{W}), 90^{\circ}(\mathrm{V})$ ) its minimum value is $4785.9 \mathrm{kN}$ (at $180^{\circ}(\mathrm{W}), 0^{\circ}(\mathrm{V})$ ). The following vessel headings yielded the highest effective tension at a specific wave direction; for $0^{\circ}$ wave direction $\left(90^{\circ}(\mathrm{V})\right)$; for $90^{\circ} \mathrm{W}\left(0^{\circ}(\mathrm{V})\right.$; $\left.180^{\circ}(\mathrm{V})\right)$; for $180^{\circ} \mathrm{W}$ $\left(90^{\circ}(\mathrm{V})\right)$; while for $270^{\circ} \mathrm{W}\left(0^{\circ}(\mathrm{V}) ; 180^{\circ}(\mathrm{V})\right)$.

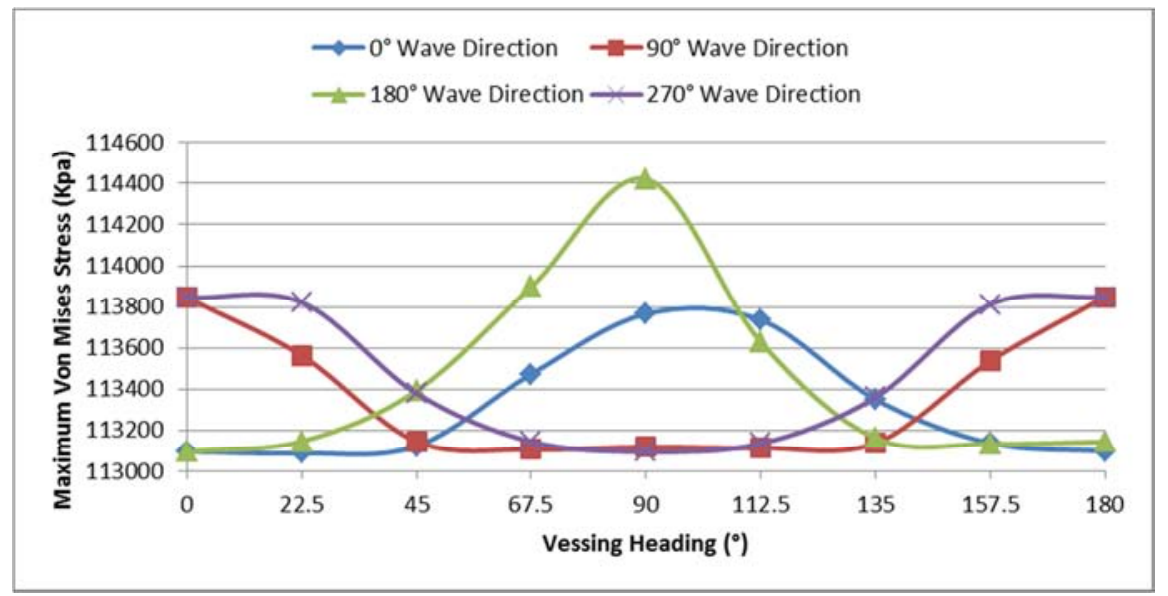

Figure 5. Maximum von Mises Stress at top end of the FSHR for 10-years wave period.

Figure 5 reveals that the maximum von Mises stress on FSHR for 10 -year wave return is $114421.3 \mathrm{kPa}$ (at $180^{\circ}(\mathrm{W})$, $\left.90^{\circ}(\mathrm{V})\right)$, while its minimum value $113088.1 \mathrm{kPa}$ occurred at
$0^{\circ}(\mathrm{W}), 22.5^{\circ}(\mathrm{V})$. The same vessel headings which yielded highest effective tension above also resulted to highest von Mises stress, hence, attention should be given to the vessel 
headings adopted to ensure that they do not impose high stress and tension on the riser system

\subsubsection{Sensitivity of Flexible Jumper (for 10-Years Wave Period)}

The same load case applied to the FSHR was also applied to the top end of the flexible jumper to check its effective tension and von Mises stress response to variation in wave direction and vessel headings. Variations in the values of effective tension and stress obtained at the FSHR and at the flexible jumper should be noted; as this shows the part of the riser system more vulnerable to tension or stress as the case maybe.

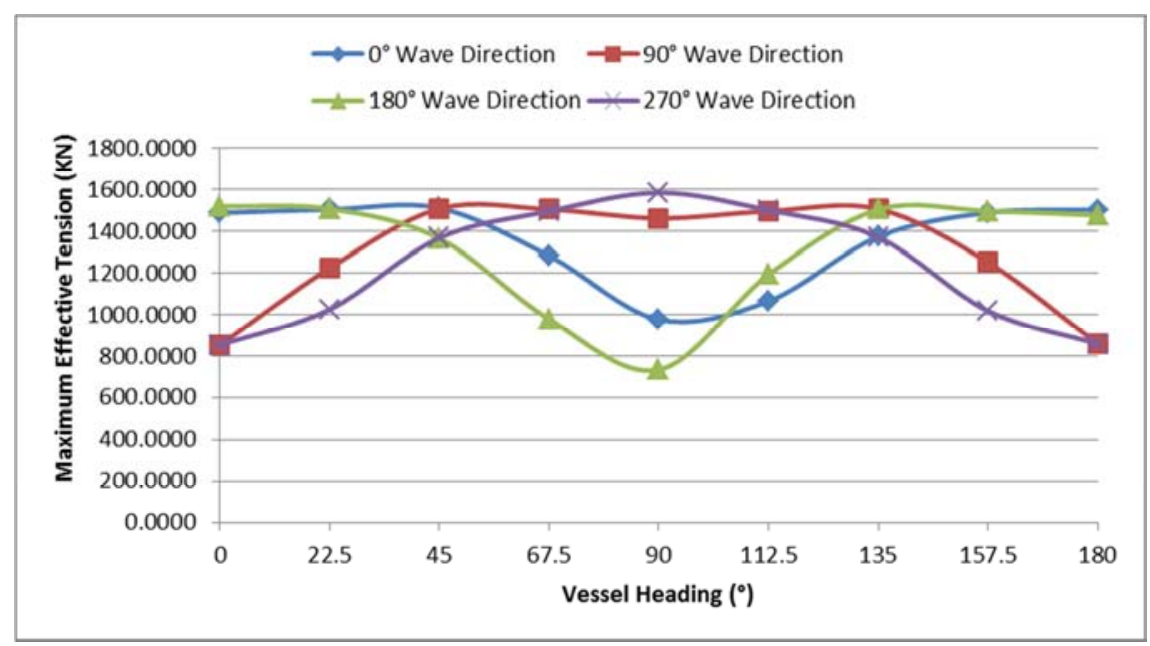

Figure 6. Maximum Effective Tension of the flexible jumper for 10-years wave period.

Based on the highest effective tension at the top end of the flexible jumper, figure 6 shows that a highest value of $1585.2 \mathrm{kN}$ (at $180^{\circ}(\mathrm{W}), 0^{\circ}(\mathrm{V})$ ) and a lowest value of $733.6 \mathrm{kN}$ (at $180^{\circ}(\mathrm{W}), 90^{\circ}(\mathrm{V})$ ) was observed from the simulation. It can also be deduced from this figure that the vessel heading(s) yielding the highest effective tension are $45^{\circ}$ and $180^{\circ}$ (for $0^{\circ} \mathrm{W}$ ); $45^{\circ}$ and $135^{\circ}$ (for $90^{\circ} \mathrm{W}$ ); $22.5^{\circ}$ and $135^{\circ}$ (for $180^{\circ} \mathrm{W}$ ); $90^{\circ}$ (for $270^{\circ} \mathrm{W}$ ).

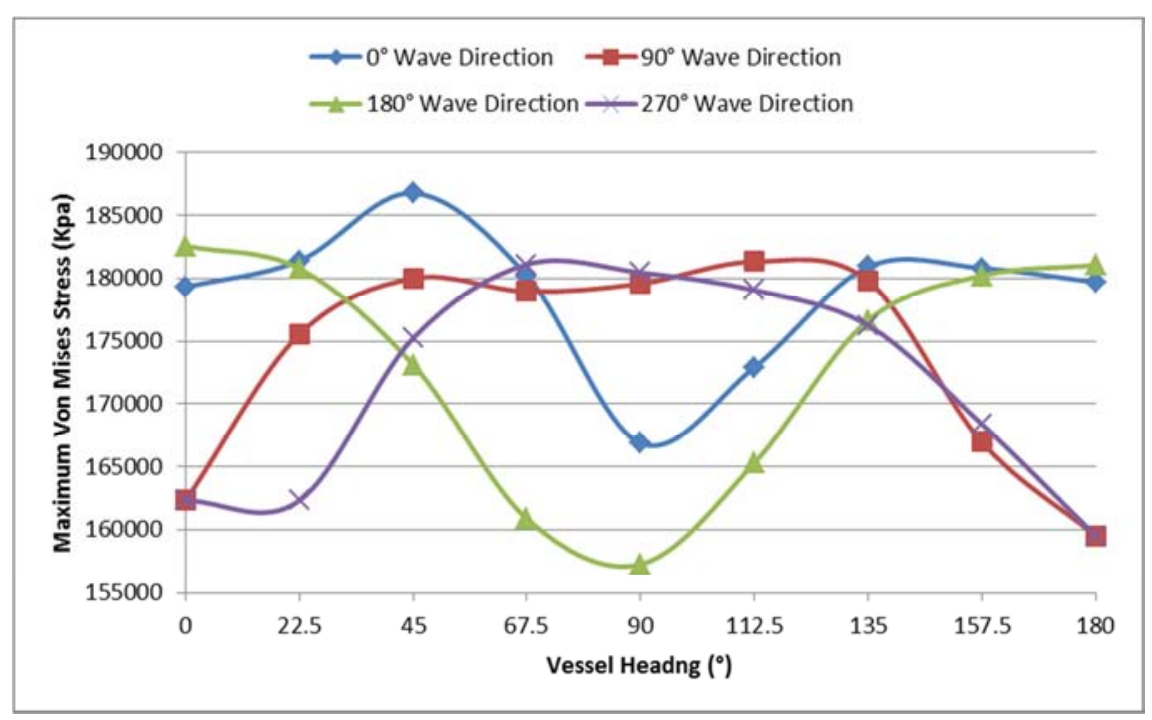

Figure 7. Maximum von Mises stress of the flexible jumper for 10-years wave period.

Considering figure 7 above, the highest von Mises stress on Flexible Jumper for 10-years wave return is $186751.5 \mathrm{kPa}$ (at $\left.0^{\circ}(\mathrm{W}), 45^{\circ}(\mathrm{V})\right)$; while its minimum values is 157253.9 $\mathrm{kPa}$ (at $180^{\circ}(\mathrm{W}), 90^{\circ}(\mathrm{V})$ ). The vessel heading yielding highest von Mises stress are as follows, $45^{\circ}$ (for $0^{\circ} \mathrm{W}$ ); $112.5^{\circ}$ (for $90^{\circ} \mathrm{W}$ ); $0^{\circ}$ (for $180^{\circ} \mathrm{W}$ ); and $67.5^{\circ}$ (for $270^{\circ} \mathrm{W}$ ).

\subsection{Design Analysis of Tethered Hybrid Riser (THR)}

The hybrid riser with the integration of a tether system was studied using the same load cases as that of the convectional hybrid riser. The tether is attached to the buoy to deliver stability and also to ensure that the design tension limit of the system is not exceeded in case of accidental scenarios which might cause damage to the system or buoy.

\subsubsection{Sensitivity of Fixed Standing Hybrid Riser (FSHR) with Integrated Tether}

With the incorporation of a tether to the conventional hybrid riser, analysis of the effective tension at the top end of 
the FSHR is shown below.

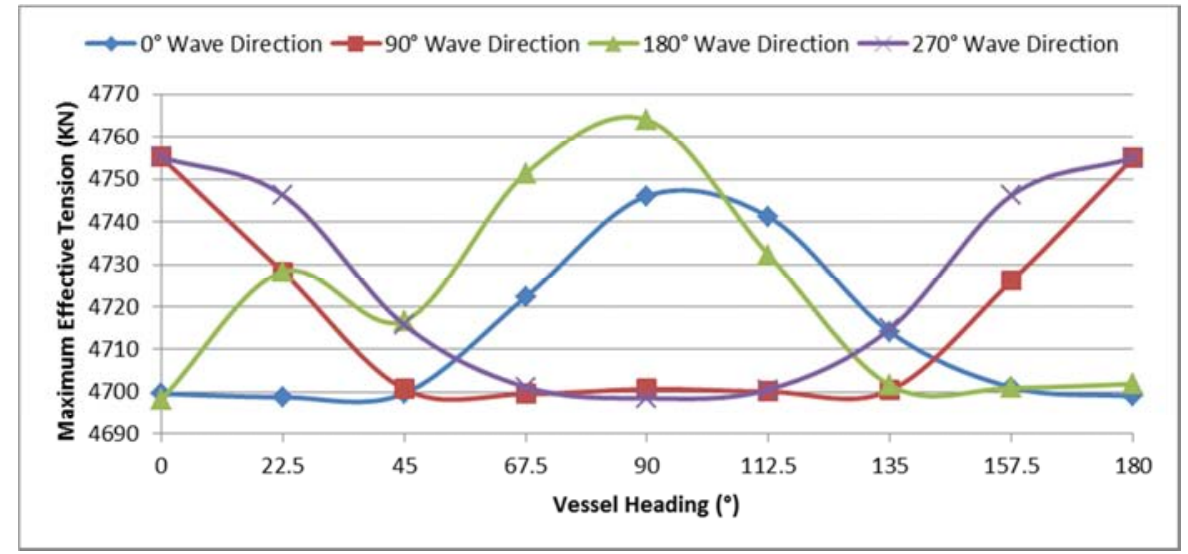

Figure 8. Effective Tension on the FSHR in THRS for 10-years wave period.

It can be deduced from figure 8 that the highest effective tension $4763.99 \mathrm{kN}$ occurred at $180^{\circ}(\mathrm{W})$, and $90^{\circ}(\mathrm{V})$. Hence, there was a reduction when compared to that of a CHR $(4881.6 \mathrm{kN})$. Also, figure 8 above shows that the lowest effective tension $4698.3 \mathrm{kN}$ occurred at $180^{\circ}(\mathrm{W})$, and $0^{\circ}(\mathrm{V})$ has a reduced value when compared to $4785.9 \mathrm{kN}$ of the $\mathrm{CHR}$; This reduction in tension can be attributed to the incorporated tether system to the CHR.

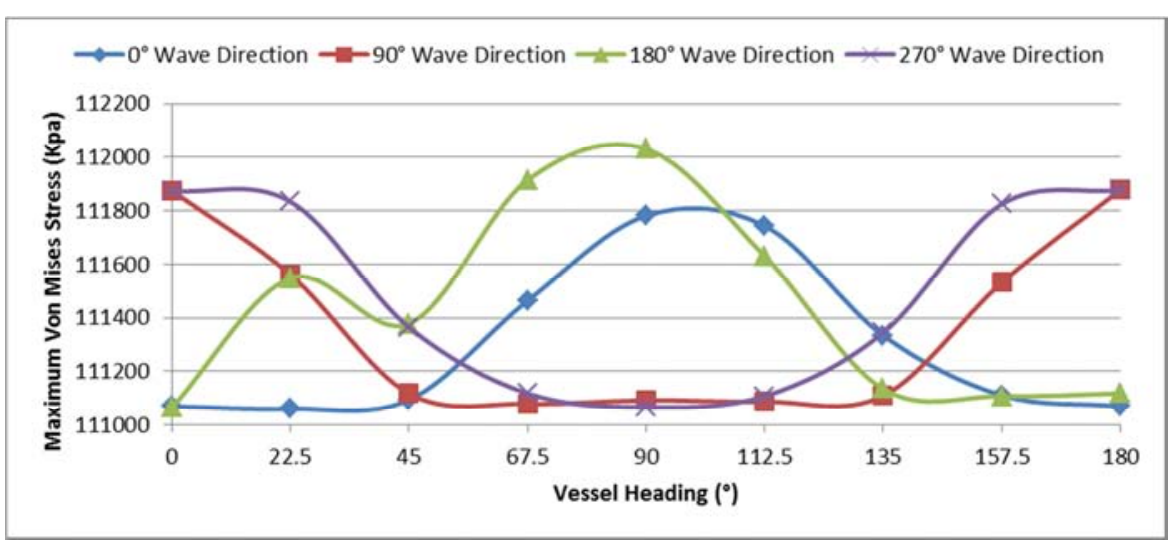

Figure 9. Maximum von Mises stress on the FSHR in THRS for 10-years wave period.

The graph in figure 9 reveals that for a THRS, the highest von Mises stress on FSHR for 10 -years wave return is $112031.2 \mathrm{kPa}$ (at $\left.180^{\circ}(\mathrm{W}), 90^{\circ}(\mathrm{V})\right)$; while its minimum value $111058.9 \mathrm{kPa}$ occurred at $0^{\circ}(\mathrm{W})$, and $22.5^{\circ}(\mathrm{V})$. These values in comparison with those of the CHR (114421.3kPa (Max.) and $113088.1 \mathrm{kPa}$ (Min.) shows a reduction in stress.

\subsubsection{Sensitivity of the Flexible Jumper for Hybrid Riser with Integrated Tether}

The analysis of the effective tension and maximum von Mises stress on the flexible jumper of a THR were also carried out in the simulation. The graphs below summarize the results.

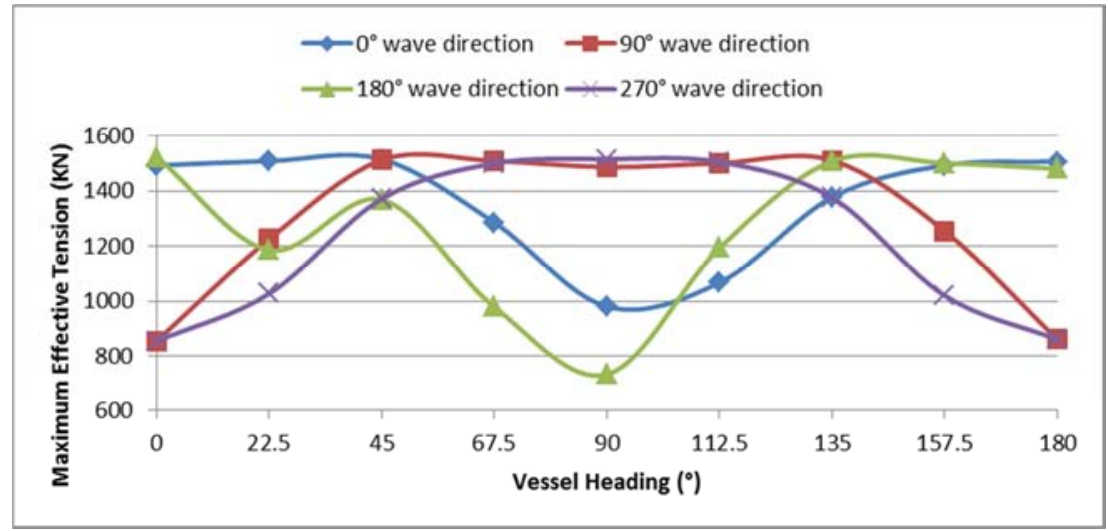

Figure 10. Effective Tension of flexible jumper in THRS for 10-years wave period. 
Figure 10 shows a reduction in the value of effective tension acting on the flexible jumper components of CHR compared to THR, with the CHR values being greater. Whereas THR showed a maximum effective tension of $1515 \mathrm{kN}$ at $270^{\circ}(\mathrm{W})$ and $90^{\circ}(\mathrm{V})$ with minimum of $732.95 \mathrm{kN}$ at $180^{\circ}(\mathrm{W})$ and $90^{\circ}(\mathrm{V})$; CHR showed a maximum effective tension of $1585.2 \mathrm{kN}$ and a minimum of $733.6 \mathrm{kN}$.

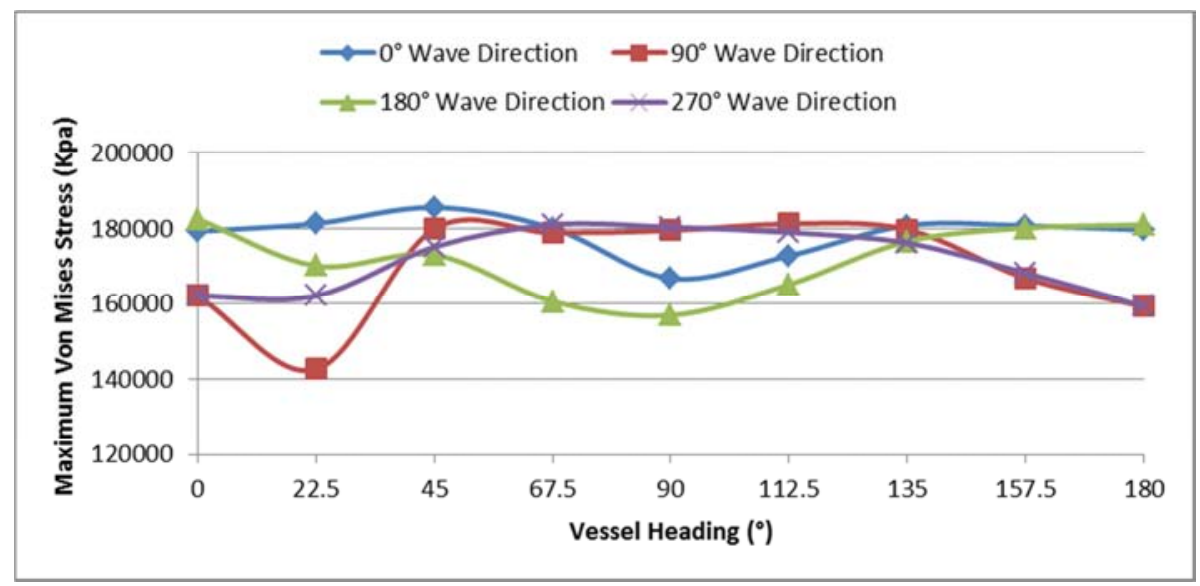

Figure 11. Maximum von Mises stress of flexible jumper in THRS for 10-years wave period.

The THR's Flexible Jumper in figure 11 above reveals that the highest von Mises stress for 10-years wave return is $185567.0 \mathrm{kPa}$, this occurred at $0^{\circ}(\mathrm{W})$ and $45^{\circ}(\mathrm{V})$; while its minimum value $142600 \mathrm{kPa}$ occurred at $90^{\circ}(\mathrm{W})$ and $22.5^{\circ}(\mathrm{V})$. There was also a reduction in the value of the von Mises stress as compared to the CHR.

\section{Conclusion}

This study investigates the optimization of the hybrid riser to improve its performance, stability and efficiency by the integration of a tether to act as station keeping and to ensure that the design tension limit of the FSHR is not exceeded. From the study, it was observed that maximum von Mises stress on the FSHR for a CHR was $114 \mathrm{MPa}$ with a tension of $4881 \mathrm{kN}$ as compared to the THR system which yielded $112.0 \mathrm{MPa}$ and a tension of $4763.0 \mathrm{kN}$; hence, a $2.5 \%$ reduction in the stress and tension was observed. The CHR's flexible jumper had a maximum von Mises stress of 186.7MPa while that of the THR riser was $185.5 \mathrm{MPa}$, hence, yielding a $6.4 \%$ reduction; their effective tensions were $1585.0 \mathrm{kN}$ and $1515.0 \mathrm{kN}$ respectively (yielding a $4.6 \%$ reduction). Also, vessel headings yielding lower tension/stress should be adopted as this will help to preserve the integrity of the riser system.

\section{Nomenclature}

CHR: Conventional Hybrid Riser

DNV: Det Norske Veritas

FEA: Finite Element Analysis

FPSO: Floating Production Storage

FSHR: Fixed Standing Hybrid Riser

GoG: Gulf of Guinea

GoM: Gulf of Mexico

IHS: Information History Service
THRS: Tethered Hybrid Riser System

SCR: Steel Catenary Riser

TTR: Top Tension Riser

SLOR: Single Line Offset Riser

THR: Tethered Hybrid Riser

FEA: Finite Element Analyses

VIV: Vortex Induced Vibration

$\mathrm{H}_{\mathrm{s}}$ : Significant Wave Height

$\mathrm{T}_{\mathrm{p}}$ : Wave pitch

$\mathrm{W}_{\mathrm{a}}$ : Weight in air

$\mathrm{W}_{\mathrm{w}}$ : Weight in water

\section{References}

[1] Mungall, J., David, L., and Charles, A. Patent No. 5639187. United States of America. 1997

[2] Yong, Bai., and Bai, Qui. "Subsea Pipelines and Risers". Oxford: Elsevier. 2005.

[3] Yong, B., and Bai, Qui. "Subsea Engineering Hand Book". Houston: Elsevier. 2010.

[4] Huang, S. "Risers and Mooring Lines". Glasgow: Department of Naval Architecture and Marine Engineering. 2004.

[5] Clausen, T., and D' Souza, R. "Dynamic risers key component for deepwater drilling, floating production". Offshore Magazine, 89-93. 2001.

[6] Mahone, W. C., Chandler, B. D., and Killeen, J. P. Patent No. 5702205. 1995

[7] Serta, O. B., Longo, C. E. V., and Roveri, F. E. "Riser Systems for Deep and Ultra-Deepwaters". Paper prepared for presentation at the Offshore Technology Conference, Houston, USA. 2001

[8] Yongming, C., Lixin, X., and Paul, S. "Design Challenges of Top Tensioned Risers in Ultra Deepwater Applications". Rotterdam: OMAE 2011-50127. 2011. 
[9] Ruxing, S., Paul, S., and Xiaoliang, Z. "Engineering Design of Deepwater Freestanding Hybrid Riser". Proceedings of the ASME 2010, 29th International Conferece in Ocean and Artic Engineering. Shan ghai: OMAE. 2010.

[10] Elizabeth, T., and Thethi, R. "The Evolution of Free Standing Risers". Proceedings of the 28th ASME 28th International Conference on Ocean, Offshore and Artic Engineering. Honolulu: OMAE 2009-79487. 2011

[11] Dale, H., and Karunakaran, D."Grouped SLOR Design and Implementation". Retrieved August 21, 2012, from WWW.2hoffshore.com:

http://www.2hoffshore.com/documents/papers/The-GroupedSLOR-Design-and-Implementation-2H-Format.pdf. 2007.

[12] Madhu, H. "Emerging Trends in Riser Technologies". Retrieved August 22, 2012, from www.2hoffshore.com: http://www.2hoffshore.com/documents/papers/EmergingTrends-in-Riser-Technologies-Ocean-Tex-Mumbai-March2010.
[13] Det Norske Veritas - DNV, “Offshore Standards DNV-OSF201 - Dynamic Risers”, October 2010.

[14] American Petroleum Institute, "API RP 2RD - Design of Risers For Floating Production Systems (FPS) and TensionLeg Platforms (TLPs)". 1998.

[15] ORCINA Limited. OrcaFlex Manual. Ulverston, Cumbria, Uniteg Kingdom. June 2012.

[16] Andueza, A., Stefan, S., and Silve, R. "Ultra-Deepwater Steel Hybrid- Riser Concept Offshore Brazil". Offshore Technology Conference (pp. 1-8). Houston: OTC 13255, 2001.

[17] American Petroleum Institute, "API-RP-2SK - Design and Analysis of Stationkeeping Systems for Floating Structures" (3rd ed.). Washington: API American Petroleum Institute. 2005 . 